\title{
PEMBELAJARAN DENGAN PENDEKATAN METACOGNITIVE GUIDANCE (MG) UNTUK MENINGKATKAN LITERASI MATEMATIS SISWA SMP
}

\author{
Elsa Komala $^{1)}$, Siti Nur Sabila Qintani ${ }^{2)}$ \\ ${ }^{1,2)}$ Universitas Suryakancani, jl. Muwardi-Cianjur Jawa Barat; \\ elsakomala@gmail.com
}

\begin{abstract}
To the effect this research is subject to see the improvement of students' mathematical literacy by using the Metacognitive Guidance (MG) approach, especially the mathematical literacy ability of level 3 and level 4 students. The design of this research is non-equivalent control group design. The experimental class is given by using the Metacognitive Guidance (MG) approach and the control class given the learning with the conventional approach. The population in this study is all students of class VII of one of the Junior High School in Cianjur. The samples were chosen as many as 2 classes from eight existing classes with purposive sampling technique. To obtain the result of research data using instrument in the form of mathematical literacy level 3 and level 4, and student questionnaire. Data processing increased the ability of mathematical literacy using mann-witney test. Based analisi data, the results showed that the improvement of students 'mathematical literacy skills using the Metacognitive Guidance (MG) approach was better than the improvement of students' mathematical literacy skills using conventional approach, the improvement was in the medium category. The questionnaire results show that students' attitude toward mathematics learning using Metacognitive Guidance (MG) approach is positive.

Keywords: Metacognitive Guidance Approach, Mathematical Literacy.
\end{abstract}

\section{Abstrak}

Penelitian ini bertujuan untuk melihat peningkatan literasi matematis siswa dengan menggunakan pendekatan Metacognitive Guidance (MG), khususnya literasi matematis siswa level 3 dan level 4. Desain penelitian ini adalah non-equivalent control grup design. Kelas eksperimen yang diberikan pembelajaran dengan menggunakan pendekatan Metacognitive Guidance (MG) dan kelas kontrol yang diberikan pembelajaran dengan pendekatan konvensional. Populasi dalam penelitian ini adalah seluruh siswa kelas VII dari salah satu SMP Negeri yang ada di Cianjur. Adapun yang dijadikan sampel dipilih sebanyak 2 kelas dari delapan kelas yang ada dengan teknik purposive sampling. Untuk mendapatkan data hasil penelitian digunkan instrumen berupa tes literasi matematis level 3 dan level 4, dan angket siswa. Pengolahan data peningkatan literasi matematis menggunakan uji mannwitney. Berdasarkan analisis data, hasil penelitian menunjukkan bahwa peningkatan literasi matematis siswa yang menggunakan pendekatan Metacognitive Guidance (MG) lebih baik dari peningkatan literasi matematis siswa yang menggunakan 
pendekatan konvensional, peningkatan yang terjadi ada pada kategori sedang. Hasil angket menunjukkan bahwa sikap siswa terhadap pembelajaran matematika dengan menggunakan pendekatan Metacognitive Guidance (MG) adalah positif.

Kata Kunci: Pendekatan Metacognitive Guidance (MG), Literasi Matematis

\section{PENDAHULUAN}

PISA (Programme for International Student Assessment) adalah studi literasi yang diselenggarakan oleh Organisation for Economic Cooperation

$\&$ Development (OECD) untuk mengukur sejauh mana kecakapan anak-anak usia 15 tahun dalam mengimplementasikan masalahmasalah di kehidupan nyata melalui tes yang meliputi kemampuan matematis (mathematical literacy), membaca (reading literacy), dan ilmu pengetahuan umum (scientific literacy).

Sejak pertama kali mengikuti PISA pada tahun 2000, prestasi siswa Indonesia di ajang ini tidak pernah beranjak jauh dari posisi terbawah, terutama pada hasil pengujian matematika. Pada PISA tahun 2003, dalam bidang matematika, Indonesia berada di peringkat 38 dari 40 negara dengan rataan skor 360. Pada tahun 2006, rataan skor siswa Indonesia naik menjadi 391, yaitu peringkat 50 dari 57 negara. Pada tahun 2009, Indonesia hanya menempati peringkat 61 dari 65 negara dengan rataan skor 371. Pada tahun 2012, Indonesia menempati posisi kedua terbawah, yaitu peringkat 64 dari 65 negara dengan rataan skor 375. Pada tahun 2015, rataan skor siswa Indonesia naik menjadi 386, yaitu peringkat 64 dari 72 negara dengan rataan skor internasional adalah 490 (Balitbang, 2016).

Hasil penilaian di atas menginterpretasikan bahwa matematika belum mampu menjadi pelajaran yang menarik minat siswa, terlihat dari prestasi siswa Indonesia yang masih mendapatkan skor di bawah rataan skor internasional. Masih rendahnya kemampuan siswa dalam menyusun strategi pemecahan masalah yang berhubungan dengan situasi nyata yang mereka temui menunjukkan bahwa pendidikan di Indonesia belum mampu menuntaskan kemampuan literasi matematis.

PISA (2015) mendefinisikan literasi matematis sebagai kemampuan seseorang untuk merumuskan, menafsirkan, dan menginterpretasi matematika dalam berbagai konteks. Termasuk kemampuan melakukan penalaran secara matematis dan menggunakan kosep, prosedur, dan fakta untuk menggambarkan, menjelaskan, atau menafsirkan fenomena/kejadian. Disamping itu, PISA juga mengukur sejauh mana kesiapan siswa usia akhir wajib belajar dalam menghadapi tantangan pembangunan masyarakat modern (modern society). Kemampuan ini akan membantu seseorang untuk memahami peran matematika di dunia nyata dan membuat penilaian serta keputusan yang berdasar pada penalaran mumpuni yang akan 
dibutuhkan dalam kehidupan bermasyarakat yang konstruktif, bersatu, dan reflektif.

Studi PISA adalah salah satu penilaian internasional yang mengamati dan mengukur literasi matematis dengan tiga gugus kompleks kemampuan matematis yang diukur, yaitu reproduksi, koneksi untuk memecahkan masalah, dan refleksi. Aspek yang diamati untuk mengukur ketiga gugus kompetensi tersebut adalah komunikasi, pemodelan, representasi, penalaran dan argumen, penggunaan strategi untuk memecahkan masalah, penggunaan bahasa simbol-formalteknis, dan pengggunaan perangkat matematis. Terdapat 6 level atau tingkatan pengetahuan matematis dimana masing-masing level mengukur tingkatan pengetahuan yang berbeda. Semakin tinggi level, semakin kompleks pengetahuan yang diperlukan. Soal yang paling mudah disusun untuk mengetahui pencapaian kompetensi reproduksi, sedangkan soal yang sulit dibuat untuk menguji kompetensi refleksi. Diantara keduanya disusun soal untuk mengetahui kemampuan siswa dengan operasi matematika yang sederhana. Pada skala menengah, soal-soal disusun sedemikian rupa sehingga untuk dapat menyelesaikan persoalan tersebut memerlukan interpretasi. Situasi yang disajikan tidak dikenal atau belum pernah dialami siswa. Pada skala atas, soal-soal yang disajikan memerlukan penafsiran tingkat tinggi dengan konteks yang sama sekali tidak terduga.
Berdasarkan temuan Maryanti (2012: 6), dalam setiap konten yang diujikan di PISA, rata-rata siswa Indonesia menduduki peringkat level dua ke bawah. Ini menunjukkan bahwa kemampuan literasi siswa di Indonesia hanya sampai pada kemampuan reproduksi, yaitu kemampuan pengoperasian matematika dalam konteks sederhana. Lemahnya siswa kita dalam menjawab soal literasi matematis level 3 sampai level 6 menunjukkan bahwa siswa kita belum mampu menginterpretasikan kemampuan matematis dalam kehidupan sehari-hari di berbagai konteks. Sejalan dengan hal tersebut kemampuan literasi matematis siswa pada level 3 dan level 4 masih lemah pada tingkatan sekolah menengah di beberapa sekolah di cianjur berdasarkan informasi beberapa mahasiswa setelah melaksanakan Program Latihan Pengajaran (PLP) pada semester ganjil tahun 2016/2017 dan perlu ditingkatkan.

Lemahnya literasi matematis siswa level 3 sampai level 4 dapat disebabkan oleh beberapa faktor, diantaranya ketika siswa berada pada kondisi kesulitan menyelesaikan soal kemampuan literasi matematis bukan disebabkan karena rendahnya kemampuan matematis yang dimiliki siswa, tetapi karena kebiasaan membaca siswa yang masih perlu diasah. Siswa tidak dapat memperoleh informasi esensial dan strategis dalam membaca soal-soal literasi matematis yang berkaitan dengan kehidupan sehari-hari. Selain itu, aspek psikologis yang mungkin turut 
memberikan pengaruh adalah kurangnya tingkat keyakinan terhadap kemampuan mereka sendiri dalam menyelesaikan soal matematika. Ketika menghadapi soal yang terlihat sedikit rumit, siswa cenderung mudah menyerah dan menganggap kegagalan berasal dari kurangnya kemampuan matematisnya.

Kemungkinan penyebab lain adalah siswa kurang terbiasa melakukan proses koneksi dalam pemecahan masalah dengan benar.

Sehubungan dengan masalah tersebut, ada keterkaitannya dengan keterampilan metakognitif yang dimiliki siswa. Metakognitif adalah suatu kesadaran berfikir dalam diri kita, sehingga kita dapat melakukan tugas-tugas khusus dan kemudian menggunakan kesadaran tersebut untuk mengontrol apa yang akan kita kerjakan. Belajar matematika merupakan suatu proses kognitif yang kompleks, yang meliputi aktivitas metakognitif yang harusnya diberikan kepada siswa, sehingga siswa tersebut memiliki keterampilan-keterampilan metakognitif. keterampilan tersebut melatih siswa untuk dapat berfikir, belajar, dan dapat mengambil keputusan sendiri secara independen. (Vygotsky dalam Jacob; 2003)

Dibutuhkan sebuah pendekatan dalam pembelajaran matematika yang mampu mengaktifkan siswa dalam mengonstruksi pengetahuannya, sehingga siswa memiliki kesadaran tentang apa yang sudah diketahui dan belum diketahuinya serta bagaimana mereka memilih strategi yang tepat untuk menyelesaikan suatu permasalahan. Salah satu alternatif pendekatan pembelajaran yang cukup relevan untuk digunakan adalah pendekatan Metacognitive Guidance (MG).

Kramarski dan Mizrachi (2004) menyatakan bahwa pendekatan pembelajaran dengan Metacognitive Guidance (MG) mampu meningkatkan kemampuan metakognitif siswa. Pendekatan ini didasarkan pada self questioning dan memfokuskan pada empat pertanyaan dasar dalam aktivitas pembelajaran. Empat pertanyaan dasar tersebut terdiri atas: (1) comprehensing questions; (2) constructing connections; (3) use of strategies; (4) reflecting. Pertanyaanpertanyaan tersebut akan dapat membantu siswa untuk memiliki keterampilan metakognitif, dengan pertanyaan-pertanyaan tersebut siswa diajarkan bagaimana memaknai suatu permasalahan sehingga mampu mendeskripsikan masalah matematis dengan bahasa mereka sendiri dan mampu memecahkan suatu permasalahan. Jika kemampuan tersebut dapat dimiliki oleh siswa, maka siswa dapat mengintrepetasikan suatu permasalahan dengan pikiran dan asumsi mereka sendiri dan pada akhirnya dapat berpengaruh pada literasi matematis siswa menuju lebih baik.

Berdasarkan hasil penelitian bahwa pendekatan Metacognitive Guidance (MG) dapat meningkatkan kemampuan literasi siswa (Scruggs, 1986; Block, 2005). Lebih lanjut, Maryanti (2012) dalam penelitiannya menyimpulkan bahwa 
pendekatan Metacognitive Guidance (MG) dapat dijadikan sebagai alternatif model pembelajaran untuk meningkatkan kemampuan literasi matematis pada kelompok tengah dan bawah.

Dengan memperhatikan beberapa hal tersebut, maka pembelajaran dengan pendekatan Metacognitive Guidance (MG) dipandang tepat dalam upaya meningkatkan kemampuan literasi matematis siswa. Penelitian ini dirancang untuk melihat peningkatan literasi matematis siswa melalui pendekatan Metacognitive Guidance (MG), khususnya mengenai literasi matematis level 3 dan level 4 dalam materi perbandingan, dan sikap siswa terhadap pembelajaran dengan menggunakan pendekatan Metacognitive Guidance (MG).

\section{KAJIAN TEORITIS}

\section{Literasi Matematis}

Literasi matematis secara etimologi dapat diartikan sebagai melek matematika. Kusumah (2012) berpendapat bahwa literasi matematis adalah kemampuan menyusun serangkaian pertanyaan (problem possing), merumuskan, memecahkan, dan menafsirkan permasalahan yang didasarkan pada konteks yang ada. Hal tersebut sejalan dengan apa yang dikemukakan oleh Isnaini (2010) yang mendefinisikan literasi sebagai kemampuan peserta didik untuk dapat mengerti fakta, konsep, prinsip, operasi, dan pemecahan masalah matematika. Menurut De Lange
(2003), literasi matematis adalah suatu kecakapan yang dimiliki oleh seorang individu untuk mengidentifikasi dan memahami peran-peran yang dimainkan oleh matematika di dunia nyata, untuk membuat pendapatpendapat yang cukup beralasan, dan untuk menggunakan cara-cara yang ada di dalam matematika untuk memenuhi kebutuhan dirinya dalam kehidupan saat ini dan yang akan datang, seperti kemampuan yang sifatnya membangun, menghubungkan, dan merefleksikan warga masyarakat.

Adapun penilaian literasi matematis yang dilakukan oleh studi PISA terdiri dari 6 tingkatan atau level dimana masing-masing level mengukur tingkatan pengetahuan yang berbeda. Soal literasi matematis level 1 dan level 2 termasuk kelompok soal dengan skala bawah yang mengukur kompetensi reproduksi. Soal literasi matematis level 3 dan level 4 termasuk kelompok soal dengan skala menengah yang mengukur kompetensi koneksi. Sedangkan, soal literasi matematis level 5 dan level 6 termasuk kelompok soal dengan skala tinggi yang mengukur kompetensi refleksi. Kemampuan yang diukur dari masingmasing level berdasarkan standar PISA adalah sebagai berikut (Draft Assessment Framework PISA, 2015). Namun di dalam penelitian ini, penilaian hanya dilaksanakan untuk level 3 dan level 4, maka kemampuan yang diukur disesuaikan, sepertiberikut. 
Literasi Matematis Siswa Level 3

Siswa mampu melaksanakan prosedur yang memerlukan keputusan secara berurutan serta dapat menerapkan strategi pemecahan masalah yang sederhana. Pada level ini, siswa dapat menginterpretasikan berdasarkan sumber informasi yang berbeda dan mengomunikasikan hasil interpretasinya (Draft Assessment Framework PISA, 2015).

\section{Literasi Matematis Siswa Level 4}

Siswa mampu bekerja secara efektif dengan model dalam situasi yang konkrit dan kompleks. Siswa dapat memilih dan mengintegrasikan representasi yang berbeda dan menghubungkannya dengan situasi nyata. Pada level ini, siswa dapat menggunakan keterampilannya dengan baik dalam mengemukakan alasan dan pandangannya sesuai dengan konteks yang ada serta dapat memberikan penjelasan dan mengomunikasikannya disertai dengan argumen yang jelas (Draft Assessment Framework PISA, 2015).

\section{PENDEKATAN}

\section{METACOGNITIVE GUIDANCE}

Metakognisi atau metakognitif pertama kali diperkenalkan oleh Flavell pada tahun 1976 (Yildirim \& Zehra: 2012) yang didasarkan pada konsep metamemori. Flavell mendefinisikan metakognisi sebagai kesadaran seseorang tentang bagaimana ia belajar, kemampuan untuk menilai kesukaran suatu masalah, kemampuan untuk mengamati tingkat pemahaman dirinya, kemampuan menggunakan berbagai informasi untuk mencapai tujuan, dan kemampuan menilai kemajuan belajar sendiri.

\section{Metacognitive Guidance (MG)} adalah sebuah sistem pendukung pembelajaran yang digunakan untuk melatih keterampilan matakognisi dimana keterampilan metakognisi ini merupakan bagian penting untuk kognisi manusia (Akyüz, Yetik, \& Keser, 2015). Pembelajaran dengan pendekatan Metacognitive Guidance (MG) digunakan untuk meningkatkan kesadaran individu dan kontrol atas pembelajaran. Pendekatan ini digunakan untuk meningkatkan keterampilan belajar siswa melalui instruksi yang sistematis (Bannert, Hildebrand, \& Mengelkamp, 2009). Selama proses pembelajaran dengan menggunakan pendekatan Metacognitive Guidance (MG), siswa didorong untuk mengamati dan menjelaskan kinerja yang dilakukan mereka sendiri melalui pertanyaan refleksi yang ditanyakan untuk meningkatkan keterampilan metakognitif (Lin \& Lehman, 1999).

\section{Pendekatan Metacognitive}

Guidance (MG) adalah pendekatan pembelajaran yang didasarkan pada dua hal, yaitu: (1) metacognitive questioning yang mengandung serangkaian empat pertanyaan metakognitif, yaitu comprehension questions, connection questions, strategic questions, dan reflection questions; (2) strategi latihan untuk memberikan penjelasan matematis dan juga umpan balik. 
Pertanyaan metakognitif dapat membantu siswa dalam memaknai suatu permasalahan, sehingga mampu mendeskripsikan masalah matematis dengan bahasa mereka sendiri dan mampu memecahkan suatu permasalahan. Dengan kemampuan tersebut, siswa dapat mengintrepetasikan suatu permasalahan dengan pikiran dan asumsi mereka sendiri dan pada akhirnya dapat berpengaruh pada literasi matematis siswa menuju lebih baik.

\section{METODE PENELITIAN}

Penelitian ini merupakan penelitian kuasi eksperimen. Populasi penelitian ini adalah siswa kelas VII salah satu SMP Negeri di Cianjur, dengan sampel dua kelas VII pada sekolah tersebut dengan penentuan sampel dilakukan dengan menggunakan teknik "Purposive Sampling”, satu kelas eksperimen yang memperoleh pendekatan Metacognitive Guidance (MG) dan satu kelas kontrol yang memperoleh pembelajaran konvensional.

Untuk mengukur peningkatan literasi matematis digunkan tes literasi matematis yang terdiri dari 6 soal tes tertulis dalam bentuk uraian. Sebelum tes dijadikan instrumen penelitian, tes tersebut diukur validitas muka terkait dengan kejelasan bahasa atau redaksional dan kejelasan gambar atau representasi dan validitas isi terkait dengan materi pokok yang diberikan dan tujuan yang ingin dicapai serta aspek kemampuan yang diukur oleh ahli (expert). Langkah selanjutnya adalah tes diujicobakan untuk memeriksa validitas item, reliabilitas, daya pembeda dan tingkat kesukarannya. Uji coba dilakukan di SMP yang sama dengan tempat penelitian tetapi pada jenjang kelas yang lebih tinggi dari kelas yang akan dilakukan penelitian. Berdasarkan skor pretes dan postes dihitung peningkatannya yang terjadi pada masing-masing siswa menggunakan rumus gain ternormalisasi.

Angket sikap siswa diberikan kepada kelas eksperimen pada akhir kegiatan berupa lembar pernyataan bertujuan untuk mengetahui sikap siswa terhadap pembelajaran matematika dengan menggunakan pendekatan Metacognitive Guidance (MG).

Angket sikap menggunakan skala Likert dengan empat pilihan jawaban, yaitu: Sangat Setuju (SS), Setuju (S), Tidak Setuju (TS), Sangat Tidak Setuju (STS) dengan skor 4, 3, 2, dan 1 untuk pernyataan positif, untuk pernyataan negatif skor merupakan kebalikannya. Empat pilihan ini berguna untuk menghindari pendapat siswa pada suatu pernyataan yang diajukan sehingga pada skala pendapat siswa tidak digunakan opsi Netral (N). Skala konsep diri dibuat dalam bentuk pernyataan sebanyak 20 pernyataan yang terdiri dari 10 pernyataan positif dan 10 pernyataan negatif.

Adapun teknik penentuan skor dilakukan dengan menghitung jumlah jawaban siswa yang diperoleh dengan menghitung persentase jawaban 
angket yang dipilih siswa. Siswa akan menunjukkan sikap positif apabila jumlah pilihan jawaban $(\mathrm{SS}+\mathrm{S})$ pada pernyataan positif lebih besar dari (TS+STS) dan pilihan jawaban (TS+STS) pada pernyataan negatif lebih besar dari $(\mathrm{SS}+\mathrm{S})$.

\section{HASIL PENELITIAN DAN PEMBAHASAN}

\section{Hasil Penelitian}

Peningkatan literasi matematis siswa pada level 3 dan level 4 dalam penelitian ini dilihat dari besarnya gain ternormalisasi (N-Gain). Berdasarkan tabel.1 ditemukan bahwa rerata $\mathrm{N}$-Gain kelas eksperimen lebih tinggi daripada rerata $\mathrm{N}$-Gain kelas kontrol.

Tabel 1.

\section{Perbandingan Rerata Skor N-Gain Literasi Matematis}

\begin{tabular}{c|c|c|c}
\hline No & Kelas & Level & $\begin{array}{c}\text { Rerata N- } \\
\text { Gain }\end{array}$ \\
\hline 1 & Eksperimen & 3 & 0,37 \\
& & 4 & 0,18 \\
2 & Kontrol & 3 & 0,22 \\
& & 4 & 0,05 \\
\hline
\end{tabular}

Pengujian peningkatan literasi matematis yang pembelajarannya menggunakan pendekatan Metacognitive Guidance lebih baik daripada pembelajaran konvensional menggunakan uji non-parametrik Mann-Whitney. Sebelum melakukan non-parametrik Mann-Whitney terlebih dahulu dilakukan pengujian normalitas data kedua kelas dengan menggunakan Shapiro-Wilk. Hasil uji nomalitas N-Gain kemampuan literasi matematis siswa pada level 3 kelas eksperimen dan kelas kontrol dengan nilai Sig berturut-turut diperoleh nilai 0,051 dan nilai 0,489 untuk data $N$ Gain. Sedangkan untuk N-Gain kelas eksperimen dan kelas kontrol level 4 diperoleh nilai Sig yang sama yaitu 0,000. Sehingga data literasi matematis level 3 berdistribusi normal sedangkan pada level 4 data berdistribusi tidak normal.

Untuk mengetahui signifikansi perbedaan rerata kedua kelas data digunakan uji statistik, untuk pasangan data yang tidak homogen digunakan Mann-Whitney sig(2-tailed $)=0,000$. Nilai $\operatorname{sig}(1$-tailed $)=1 / 2 \operatorname{sig}(2$-tailed $)$ berarti sig $(1$-tailed $)=1 / 2(0,000)=$ 0,000 untuk level 3 sedangkan untuk level $4 \operatorname{sig}(2$-tailed $)=0,021$. berarti sig $(1$-tailed $)=1 / 2(0,021)=0,0105$ (Widiarso, 2008). Selanjutnya diperoleh untuk level 3 dan level 4 sig(1-tailed) < 0,05. Berarti, peningkatan literasi matematis siswa kelas eksperimen lebih baik daripada peningkatan literasi matematis siswa kelas kontrol. 
Untuk mengetahui sikap dan tanggapan siswa terhadap pembelajaran matematika dengan menggunakan pendekatan Metacognitive Guidance (MG) dan difokuskan pada tiga aspek pengukuran dimana sikap siswa terhadap ketiga aspek tersebut adalah positif. Pertama, sikap siswa terhadap mata pelajaran matematika dengan persentase sikap positif $81 \%$. Kedua, sikap siswa terhadap pendekatan Metacognitive Guidance (MG) dengan persentase sikap positif $83 \%$. Sikap siswa terhadap soal literasi matematis dengan persentase sikap positif $76 \%$.

Tabel 2.

Persentase Sikap Siswa

\begin{tabular}{|c|c|c|c|}
\hline No & Indikator & $\begin{array}{c}\text { Persentase } \\
\text { Pilihan } \\
\text { Jawaban } \\
\end{array}$ & Keterangan \\
\hline & $\begin{array}{l}\text { Sikap siswa terhadap mata } \\
\text { pelajaran matematika }\end{array}$ & $81 \%$ & $\begin{array}{l}\text { Hampir Seluruhnya } \\
\text { Positif }\end{array}$ \\
\hline & $\begin{array}{l}\text { Sikap siswa terhadap } \\
\text { pendekatan Metacognitive } \\
\text { Guidance (MG) }\end{array}$ & $83 \%$ & $\begin{array}{l}\text { Hampir Seluruhnya } \\
\text { Positif }\end{array}$ \\
\hline & $\begin{array}{l}\text { Sikap siswa terhadap soal } \\
\text { literasi matematis }\end{array}$ & $76 \%$ & $\begin{array}{l}\text { Hampir Seluruhnya } \\
\text { Positif }\end{array}$ \\
\hline & $\begin{array}{c}\text { ata Persentase Sikap Positif } \\
(\%)\end{array}$ & $80 \%$ & $\begin{array}{c}\text { Hampir } \\
\text { Seluruhnya Positi }\end{array}$ \\
\hline
\end{tabular}

Karena diperoleh persentase sikap siswa terhadap ketiga aspek pengukuran adalah positif, maka sikap keseluruhan siswa terhadap pembelalajaran dengan menggunakan pendekatan Metacognitive Guidance (MG) juga positif dengan perolehan rerata persentase sikap positif sebesar $80 \%$.

Sikap positif siswa terhadap pembelajaran dengan menggunakan pendekatan Metacognitive Guidance (MG) dapat terjadi karena selama prosesnya, siswa diberikan pembelajaran yang menyenangkan, salah satunya dengan pemberian hadiah atau reward untuk siswa yang memberikan respon terhadap pembelajaran dengan menggunakan pendekatan Metacognitive Guidance
(MG), pembentukan kelompok selama proses pembelajaran, dan pengerjaan soal-soal literasi matematis yang berhubungan dengan kehidupan sehari-hari.

Peningkatan literasi matematis siswa dengan menggunakan pendekatan Metacognitive Guidance (MG) dapat terjadi karena selama proses pembelajaran berlangsung, siswa dibiasakan untuk menilai kesukaran suatu masalah, mengamati tingkat pemahaman dirinya, menggunakan berbagai informasi untuk mencapai tujuan, dan menilai kemajuan belajar sendiri, sehingga siswa lebih cepat dalam memahami konsep dan mampu mengembangkan literasi matematis dengan baik. Siswa juga dibiasakan untuk menyelesaikan 
soal-soal literasi matematis dengan baik dan

benar, serta diberikan motivasi untuk terbiasa menyelesaikan dan mengutarakan penyelesaian dari soalsoal literasi matematis yang diberikan.

\section{KESIMPULAN DAN SARAN}

\section{Kesimpulan}

Berdasarkan hasil penelitian yang telah dilakukan pada siswa kelas VII semester 2 tahun ajaran 2016/2017 di salah satu SMP Negeri yang ada di Cianjur bahwa: peningkatan literasi matematis siswa dengan menggunakan pendekatan Metacognitive Guidance (MG) lebih baik daripada peningkatan literasi matematis siswa dengan menggunakan pendekatan konvensional; dan sikap siswa terhadap pembelajaran dengan menggunakan pendekatan Metacognitive Guidance (MG) adalah positif.

\section{Saran}

Adapun bedasarkan saran sebagai berikut: 1) Pembelajaran dengan menggunakan pendekatan Metacognitive Guidance (MG) hendaknya dilakukan dalam pembelajaran matematika, sehingga dapat meningkatkan literasi matematis siswa; 2) Perlu dilakukannya pengembangan oleh pihak sekolah melalui MGMP Matematika berkaitan dengan soal-soal literasi matematis yang diberikan agar siswa terbiasa mengerjakan soal-soal tersebut; 3) Bahasan matematika yang dikembangkan dalam penelitian ini hanya pada jenjang SMP, sehingga perlu dilakukan penelitian pada jenjang pendidikan yang berbeda, seperti SD dan SMA; 4) Selama proses pembelajaran berlangsung, bagi siswa yang memberikan respon terhadap pembelajaran matematika dengan menggunakan pendekatan Metacognitive Guidance (MG) hendaknya diberikan hadiah atau reward.

\section{DAFTAR PUSTAKA}

Akyüz, Yetik, \& Keser. (2015). Effects of Metacognitive Guidance on Critical Thinking Disposition. Pegem Journal of Education and Instruction. Pegem Egitim ve Ögretim Dergisi, 5(2), 133-148.

Bannert, M., Hildebrand, M., \& Megelkamp, C. (2009). Effects of A Metacognitive Support Device in Learning Environments. Computers in Human Behavior, 25, 829-835.

Badan Penelitian dan Pengembangan (Balitbang). (2016). Laporan Hasil TIMSS 2007. Kementerian Pendidikan dan Kebudayaan.

Block, C, C. et all. (2005). Metacognition and Literacy Learning: Theory Assessment and Instruction and Professional Development. London, Routledge.

De Lange, J. (2003). Mathematics for Literacy, In Quantitative Literacy, Why Numeracy Matters for Schools and Colleges. Proceeding of the National Forum on Quantitative Literacy. Washington D. C: National Academy of Science. 
Isnaini, N. T. (2010). Membina Lomba Melek Matematika di Sekolah. Makalah disampaikan pada Seminar Nasional Pendidikan dalam rangka Ulang Tahun Emas UNSRI di Palembang, 16 Oktober 2010.

Jacob, C. (2003). Konstruktivisme \& Metakognitif. Bandung: Universitas Pendidikan Indonesia.

Kusumah, Y. S. (2012). Literasi Matematis. Disajikan pada Seminar Nasional Matematika, Universitas Bandar Lampung.

Kramarski, B \& Mizrachi. (2004). Enhancing Mathematical Literacy with the Use of Metacognitive Guidance in Forum Discussion. Proceedings of the 28th Conference of the International Group for the Psychology of Mathematics Education. [online]. Tersedia di: http://www.dm.unipi.it/ didattic a/CERME3/Proceedings/Groups /TG8/TG8Kramarski_cerme3.pd f. [24 Desember 2016].

Lin, X. \& Lehman, J. D. (1999). Supporting Learning of Variable Control in A Computer-Based Biology Environment: Effects of Prompting College Students to Reflect on Their Own Thinking. Journal of Research in Science Teaching, 36-837-858.
Maryanti, E. (2012). Peningkatan Literasi matematis Siswa Melalui pendekatan Metacognitive Guidance. Tesis. Universitas Pendidikan Indonesia (UPI) Bandung. Tidak Diterbitkan.

OECD. (2015). Draft PISA 2015 Assessment Framework. OECD Publishing.

Scruggs, T.E. dkk. (1985). Maximizing What Gifted Student can Learn: Recent Finding of Learning Strategy Research. In Gifted Child Quarterly, 181-185. EJ 333116.

Widiarso, W. (2011). Mengaplikasikan Uji-t untuk Membandingkan Gain Score antar Kelompok dalam Eksperimen. Yogyakarta: FP UGM.

Yildirim, S. \& Zehra. (2012). The Relationship Between Students' Metacognitive Awereness and Their Solution to Similar Type of Mathematical Problems. [Online]. Diakses dari Eurasia journal of Mathematics, Science, and Technology Education. [10 Mei 2016].

Widiarso, W. (2011). Uji Hipotesis Komparatif. Yogyakarta: FP UGM. 
